\title{
The annual cycle of the community of aquatic Coleoptera (Adephaga and Polyphaga) in a rehabilitated wetland pond : the Laguna de La Nava (Palencia, Spain)
}

\author{
L.F. Valladares ${ }^{1}$ \\ J. Garrido2 \\ B. Herrerol
}

Keywords : Aquatic Coleoptera, rehabilitated wetland, ecology, phenology, Spain.

Aquatic beetles were sampled on a monthly basis between July 1991 and June 1992 in the wetland pond of La Nava de Fuentes (Palencia), a rehabilitated wetland intended to restore just part of the ancient Laguna de La Nava, one of the biggest wet areas in continental Spain until its virtual disappearance in the 1950s.

The ecology and the phenology of 50 species are described, and discussed to determine the degree of maturity reached by this newly created wetland.

Coléoptères aquatiques d'un marais réhabilité : La Nava (Palencia, Espagne). Etude d'un cycle annuel

Mots-clés : Coléoptères aquatiques, marais réhabilité, écologie, phénologie, Espagne.

Les coléoptères aquatiques ont été échantillonnés mensuellement pendant une année (Juillet 1991 - Juin 1992) dans l'étang de la Nava de Fuentes (Palencia), un marais réhabilité qui essaie de récupérer une partie de l'ancienne Laguna de la Nava, l'une des plus grandes zones humides de "L'Espagne Continentale ".

Une étude écologique et phénologique des cinquante espèces identifiées a été réalisée et le degré de maturité de la zone humide recrée est discuté.

\section{Introduction}

The pioneering work by Fernando (1958) stands out among the studies on the ecological succession of aquatic insects. Since then, useful references in connection with aquatic beetles in European waters have been published in much more recent works by Caspers (1983), Hebauer (1984, 1988), Löberbusch (1985) and Eyre et al. (1992).

Nonetheless, the patterns of ecological and seasonal succession of specific taxa (e.g. Coleoptera) in restored wetland areas are practically unknown in Spain. Undertaking their study can yield interesting information about the development of the

i. Departamento de Ciencias Agroforestales. Universidad de Valladolid. Avda de Madrid, 57. 34004 Palencia (España).

2. Departamento de Recursos Naturales y Medio Ambiente. Facultad de Ciencias. Universidad de Vigo. 36200 Vigo (España). biological community in wetland ecosystems and will help to determine which taxa are present as well as their significance in connection with the degree of maturity reached by restored ecosystems.

The Laguna de La Nava, « the sea of Castile or of Campos " as it used to be called, is located some $12 \mathrm{~km}$ West of Palencia city (Fig. 1), in the heart of the northern Iberian plateau. Its original expanse was over 2,000 ha in years of average rainfall, and up to 5,000 ha in exceptionally rainy years, with a maximum water depth of $1.8 \mathrm{~m}$. It was the most important inland wetland ecosystem in the Iberian peninsula. Although ever since the fifteenth century plans to drain the pond were repeatedly considered, it was not until 1804 that the actual drainage of the pond started. By 1950 the whole wetland had been virtually wiped out.

In the spring of 1990 a project (Jubete 1992) was launched to restore 60 ha of the former pond near the village of Fuentes de Nava. To encourage 


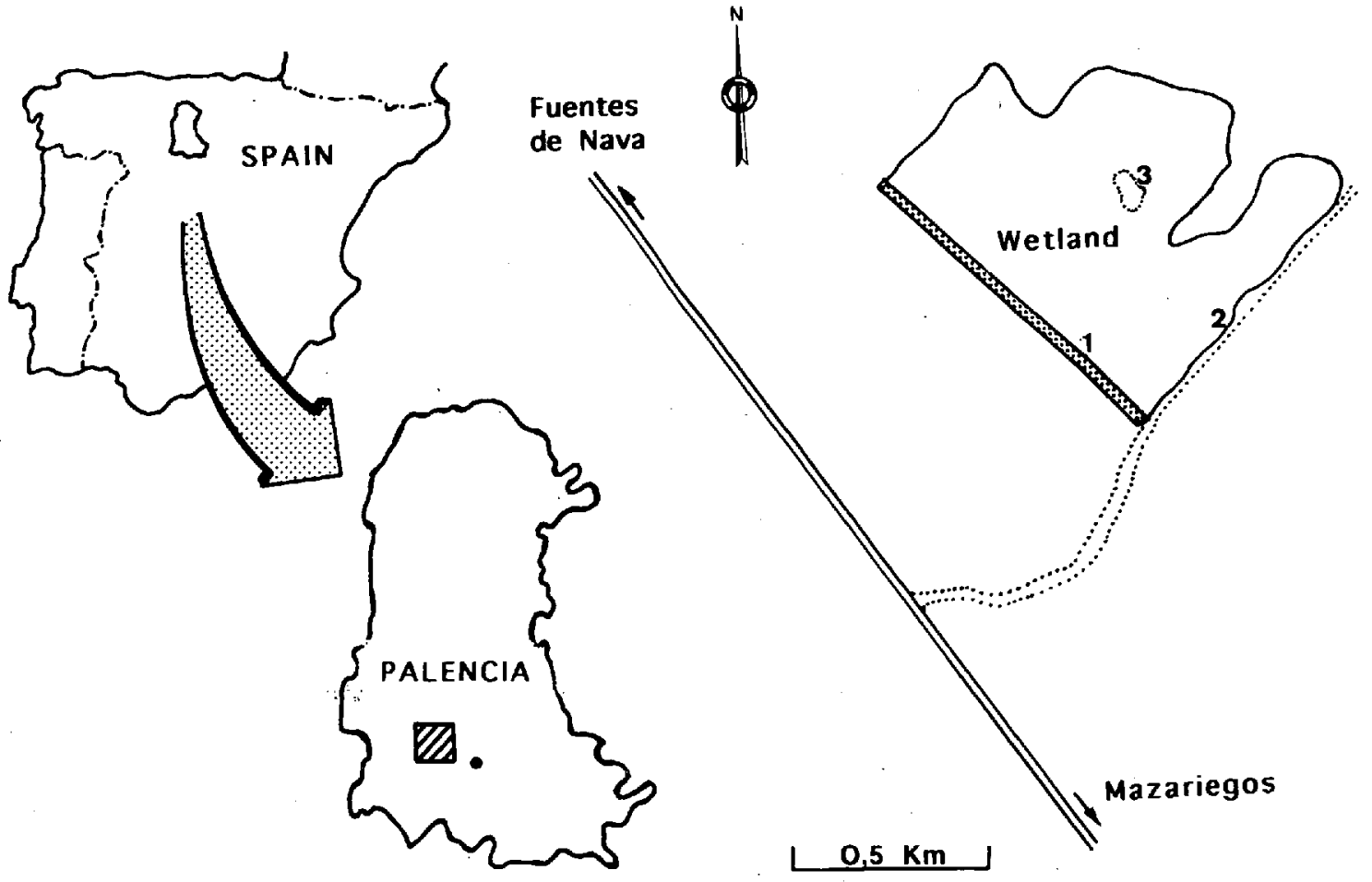

Fig. 1. Geographical situation of the Laguna de La Nava (Palencia) and location of sampling stations.

Fig. 1. Situation géographique de la Laguna de La Nava (Palencia) et localisation des stations d'échantillonnage.

flooding of the area a simple earth dike was built at the lower end of the slope (Fig. 1). Once a permanently flooded area was re-established, the wetland rapidly recovered its macrophytic vegetation which totally covers it, presenting thus a certain resemblance to the original wetland.

\section{Methodology}

Between July 1991 and June 1992, monthly samples of aquatic beetles, mainly adults, were captured in three selected stations of the restored pond at Fuentes de Nava. A brief description of the sampling sites is given (Fig. 1) :

- Station 1 (St-1): Positioned at the earth dike. Vegetation (Juncus, Carex) starts at $20-30 \mathrm{~cm}$ from the shore. Clayey substratum.

- Station 2 (St-2) : At the eastern shore of the wetland. The water's edge presents vegetation (Carex, Phragmites, Juncus) ; deeper than St-1. Water is muddier and richer in organic matter.
- Station 3 (St-3) : Deepest site in the wetland due to a residual small pond which predates the restoration project. There is plenty of marginal vegetation (Thypha, Juncus, Plantago, Ranunculus) but, because of its greater depth, the centre lacks vegetation. The water level hardly fluctuates as it is continuously being fed with water.

The beetles were collected with a semicircular net of $40 \mathrm{~cm}$ in diameter and a $250 \mu \mathrm{m}$ mesh. At every station captures from the shore, of which a $3 \mathrm{~m}$ stretch was sampled, were kept apart from those collected within a $10 \mathrm{~m}$ transect towards the middle of the wetland pond. Sampling intensity ( 3 replicates by the shore and 2 in the transect) and the sampling area were kept unchanged throughout the survey. Such procedures allow realistic comparison in order to establish trends in species abundance (Landin 1976, Montes et al. 1985). A total number of 2508 specimens was studied. 
In addition to the samples of water beetles, four physicochemical parameters were measured at each station : water temperature, $\mathrm{pH}$, conductivity, and dissolved oxygen concentration. The seasonal varia-

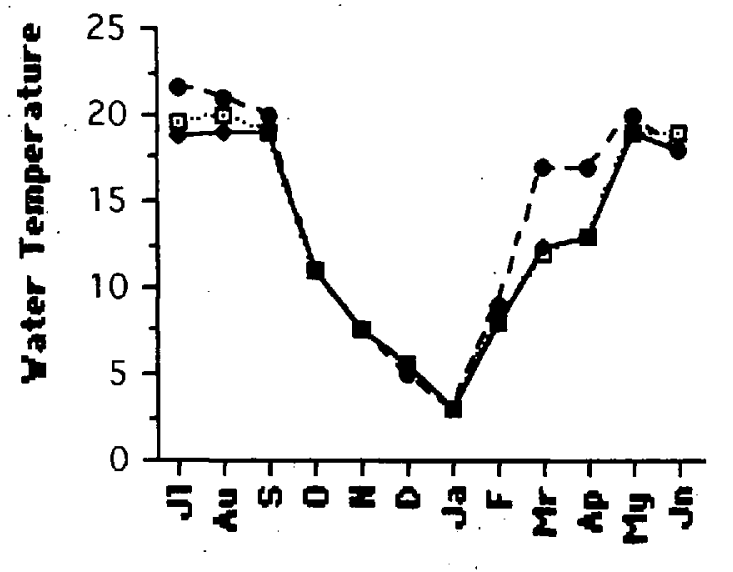

MONTHLY

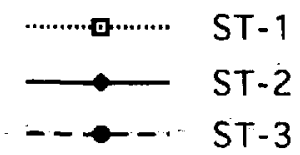

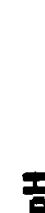

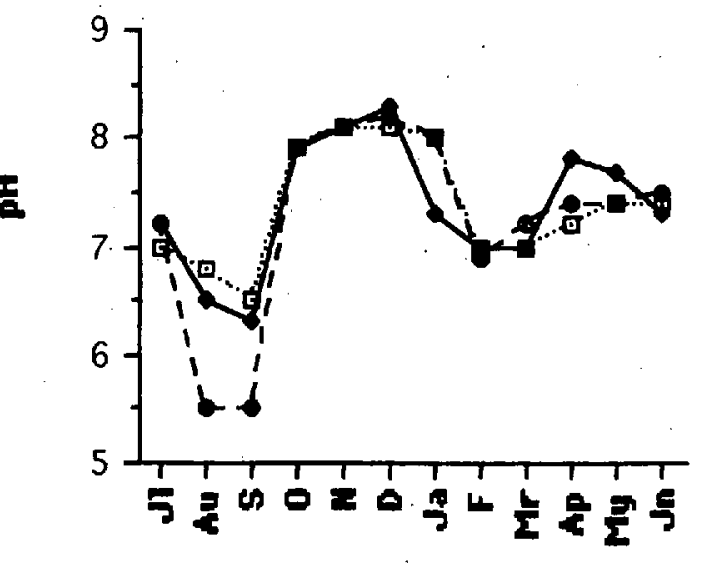

MONTHLY tions of these factors are shown in Figure 2. All three stations recorded rather uniform readings. Only St-3 showed an increased conductivity during the winter months most likely due to solutes from farming ;

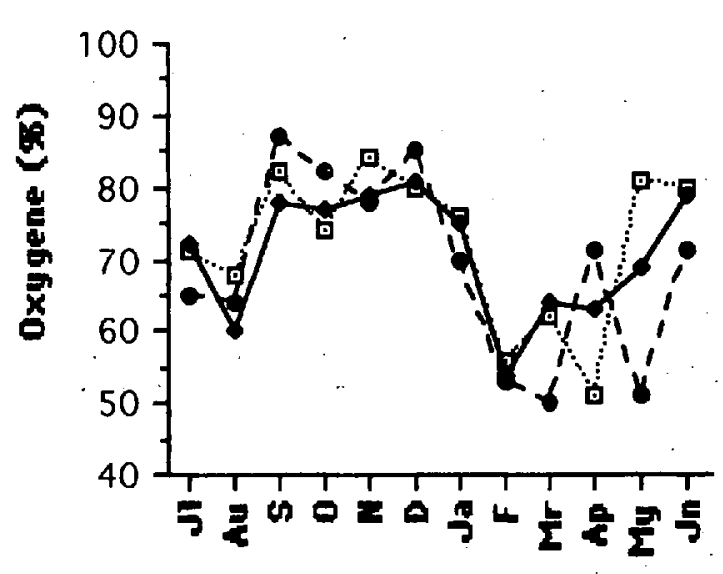

MONTHLY

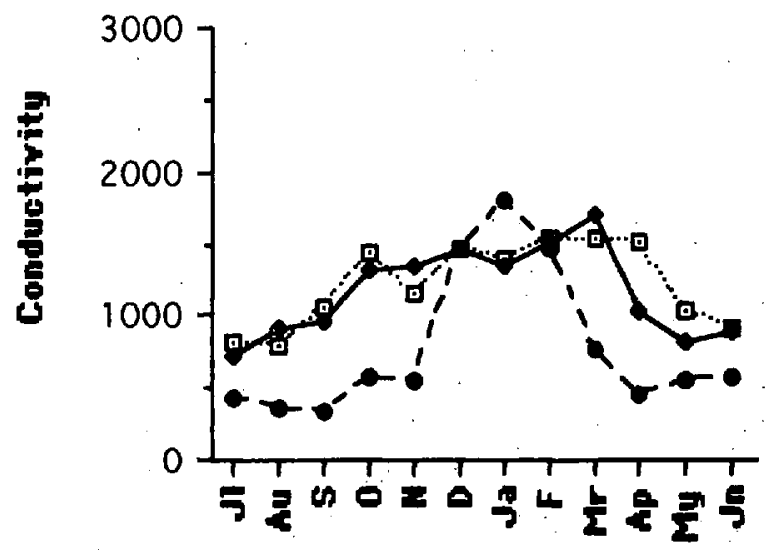

MONTHLY

Fig. 2. Seasonality of physicochemical parameters : water temperature, dissolved oxygen concentration, $\mathrm{pH}$ and conductivity.

Fig. 2. Variation des paramètres physiques et chimiques : température de l'eau, oxygène dissous, pH et conductivité. 
the surrounding area is devoted to extensive cereal cropping and fertiliser applications are common at this time of the year.

Fluctuations in the water level have been negligible because water has been artificially supplied since the restoration project began and therefore throughout the year-long study. This has kept water levels within a very narrow range $(12 \mathrm{~cm})$ making possible a prompt establishment of vegetation. Needless to say, such small variations hardly correspond with those likely to occur in natural annual cycles. As it was, the minimum levels were recorded during September and especially during October while maximum flooding occurred in March.

\section{Results and discussion}

\subsection{Community composition}

A total of 50 species of aquatic Coleoptera were identified, 24 Hydradephaga and 26 Polyphaga :

\section{ADEPHAGA}

HALIPLIDAE

Haliplus (Haliplus) heydeni Wehncke, 1875

Haliplus (Neohaliplus) lineatocollis (Marsham, 1802)

HYGROBIIDAE

Hygrobia hermanni (Fabricius, 1775)

NOTERIDAE

Noterus clavicornis (De Geer, 1774)

Noterus laevis Sturm, 1834

DYTISCIDAE

Hyphydrus (Hyphydrus) aubei Ganglbauer, 1892

Yola (Yola) bicarinata (Latreille, 1804)

Bidessus goudoti (Castelnau, 1834)

Hydroglyphus pusillus (Fabricius, 1781)

Coelambus fresnedai Fery, 1992

Coelambus impressopunctatus (Schaller, 1783)

Hydroporus (Hydroporus) palustris (Linnaeus, 1761)

Hydroporus (Hydroporus) planus (Fabricus, 1781)

Graptodytes bilineatus (Sturm, 1835)

Graptodytes flavipes (Olivier, 1795)

Laccophilus minutus Linnaeus, 1758

Agabus (Gaurodytes) bipustulatus (Linnaeus, 1767)

Agabus (Gaurodytes) melanocornis Zimmermann, 1915

Agabus (Gaurodytes) nebulosus (Forster, 1771)

Rhantus (Rhantus) hispanicus Sharp, 1880-82
Rhantus (Rhantus) suturalis (Mac Leay, 1825)

Colymbetes fuscus (Linnaeus, 1758)

Dytiscus (Macrodytes) marginalis Linnaeus, 1758

Cybister (Cybister) lateralimarginalis (De Geer, 1774)

\section{POLYPHAGA}

\section{HYDRAENIDAE}

Ochthebius (Asiobates) aeneus Stephens, 1835

Ochthebius (Asiobates) dilatatus Stephens, 1829

Ochthebius (Aulacochthebius) exaratus Mulsant, 1844

Ochthebius (Ochthebius) marinus (Paykull, 1789)

Ochthebius (Ochthebius) viridis Peyron, 1858

Limnebius furcatus Baudi, 1872

HYDROCHIDAE

Hydrochus flavipennis Küster, 1852

HELOPHORIDAE

Helophorus (Trichelophorus) alternans Gené, 1836

Helophorus (Helophorus) maritimus Rey, 1885

Helophorus (Rhopalhelophorus) asturiensis Kuwert, 1885

Helophorus (Rhopalhelophorus) griseus Herbst, 1793

Helophorus (Rhopalhelophorus) lapponicus Thomson, 1854

Helophorus (Rhopalhelophorus) minutus Fabricius, 1775

Helophorus (Atracthelophorus) bameuli Angus, 1987

Helophorus (Atracthelophorus) brevipalpis Bedel, 1881

\section{HYDROPHILIDAE}

Berosus (Berosus) affinis Brullé, 1835

Berosus (Berosus) signaticollis (Charpentier, 1825)

Enochrus (Lumetus) fuscipennis (Thomson, 1884)

Enochrus (Methydrus) isotae Hebauer, 1981

Helochares lividus (Forster, 1771)

Helochares punctatus Sharp, 1869

Hydrobius fuscipes (Linnaeus, 1758)

Hydrochara flavipes (Steven, 1808)

Hydrophilus pistaceus (Castelnau, 1840)

Limnoxenus niger (Zschach, 1788)

\section{DRYOPIDAE}

Dryops algiricus (Lucas, 1849) 
The outstanding faunistic features are the presence of Coelambus fresnedai Fery, 1992 in the Nava, recently described from the central and eastern areas of Spain (Fery 1992) and Ochthebius marinus (Paykull, 1789) whose presence in the Iberian peninsula has been recently confirmed by records from Albacete and Murcia (Delgado et al. 1991) and Andalucía (Jäch 1991).

The faunistic composition is very similar for all three sampling stations except for the greater specific richness of Hydraenidae at St-1, a result of the greater number of Ochthebius species by the earth dike forming the shore at this station. The strong similarity between stations can be shown by plotting (Fig. 3) Sorensen's affinity index (1948), based on the presence-absence criterion. St-1 and St-2 show similarity above $80 \%$; when St-3 is included it drops to $70 \%$. St-3, the deepest and oldest part of the pond, with the largest marginal vegetation, shows a clear differentiation with respect to Adephaga, whereas St-1, with a clay shore and poor vegetation, highlights Polyphaga, two of its genera, Helophorus and Ochthebius, being very well represented.

Each sampling station recorded 4 species absent from the other two sites :

- St-1 : Ochthebius aeneus, Ochthebius dilatatus, Ochthebius viridis and Helophorus maritimus.

- St-2 : Haliplus heydeni, Graptodytes flavipes, Helophorus lapponicus and Dryops algiricus.

- St-3 : Hygrobia hermanni, Yola bicarinata, Hydroporus palustris and Rhantus hispanicus.

The explanation of these exclusive distribution can be found in the autoecology of the species. At St-1 there are species restricted to a clayey shore with little vegetation and shallow waters. The species at St-2 belong to an area with more macrophytes (Dryops, Graptodytes) or with abundance of detritus (Haliplus heydeni). At St-3, there are 4 species of Hydradephaga characteristic of deep ponds with marginal vegetation. Thus, Hygrobia hermanni has an optimum of $1 \mathrm{~m}$ depth and a muddy bottom rich in Tubificidae as food resource (Balfour-Browne 1922, Montes et al. 1982).

From a quantitative and phenological standpoint, Ochthebius viridis is the most noteworthy species among those exclusive to just one sampling site. It is a very abundant species ( 125 specimens recorded) and, in effect, it is present throughout the whole

\section{S§RENSEN INDEX}
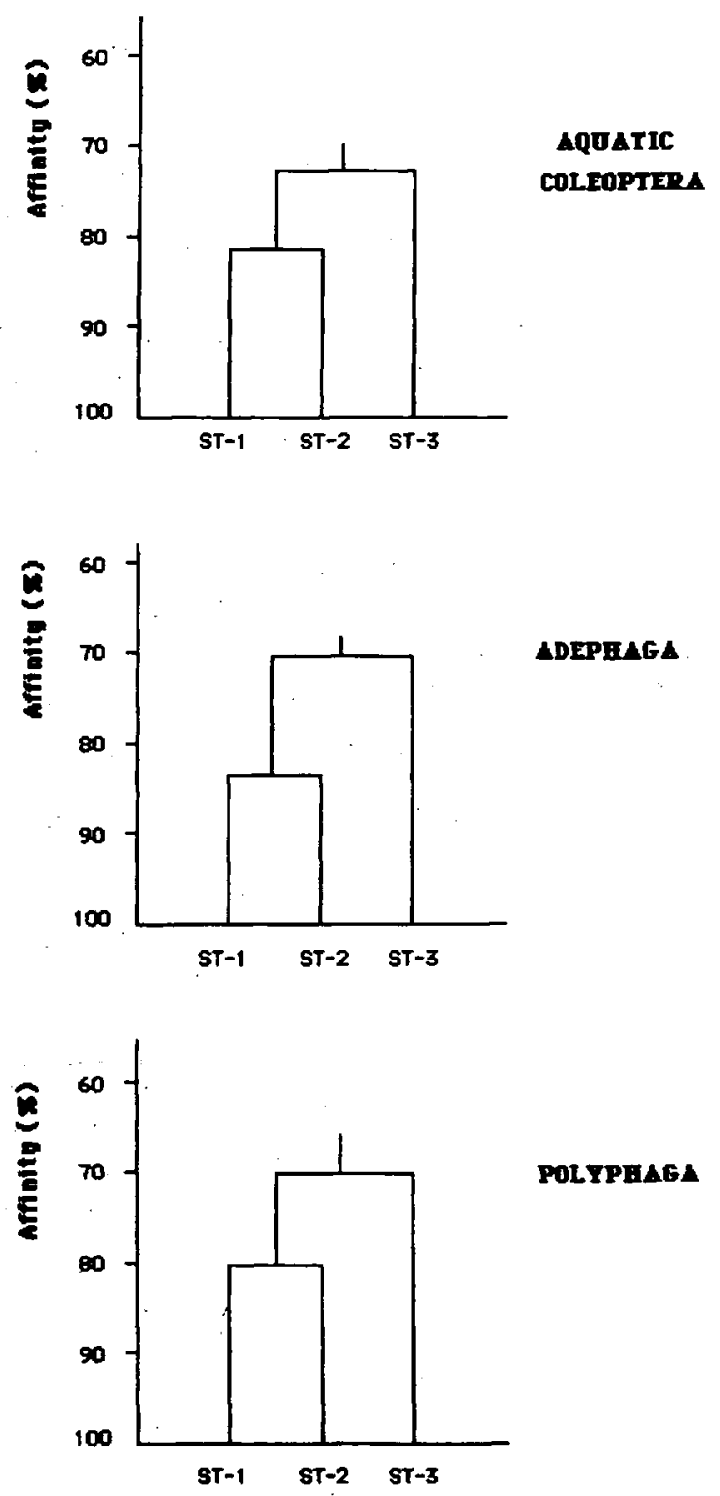

ADEPAAGA

POLTPEAga

Fig. 3. Dendrogram of faunistic affinity between sampling stations.

Fig. 3. Dendrogramme de l'affinité faunistique entre les différentes stations.

annual cycle. In contrast, very few specimens ( 1 to 4) of the other exclusive species were recorded, having been captured randomly on just 1 or 2 of the monthly visits. Although this may be difficult to prove, it would seem that $O$. viridis shows a fairly strict requirement for a substrate found in St-1. 


\subsection{Phenology}

Table 1 shows the species phenology during the annual cycle along with the number of specimens captured for each species on a monthly basis. The phenological study of most species is based on the presence of adults since the capture of larvae has been sporadic on account of the specific methodology it usually demands. For the phenological study, given the reduced size of the wetland pond and its homogeneity, all captures from the three stations have been lumped together.

In the taxocenosis as a whole, various groups of species may be distinguished according to their phenology and abundance :

- Species occurring throughout the year in the pond, with reasonable seasonal variations in population. These are dominant species such as Hydroglyphus pusillus, Laccophilus minutus, Ochthebius viridis, Limnebius furcatus, Helophorus griseus, Helophorus minutus or Helochares lividus, generally pioneers or good colonizers (Hebauer 1988).

- Species of frequent occurrence during the annual cycle such as Coelambus fresnedai, Rhantus suturalis, Berosus signaticollis or Enochrus fuscipennis.

- Species of intermittent occurrence during the annual cycle. About half of the captured species belong to this group.

- Species of sporadic occurence as a result of either a seasonally determined colonization, e.g. Rhantus hispanicus, or a short-term phenology of adults, as it is the case with several winter species of genus Helophorus.

For some of the species there were enough captures to establish their phenology in the wetland :

\section{* Hygrobia hermanni (Fabricius, 1775) (Fig. 4a)}

Although the number of specimens captureds is low, the presence of larvae and adults in just one station (St-1) and the information available in the relevant bibliography allows us to anticipate the phenology of this species in the area. Adults were captured in most of the samples, except in winter and early spring. The presence of larvae in the months of spring-summer transition (May-June-July) confirms what had already been shown (Franciscolo 1979), i.e. that larvae require three months for their full development into adults. These data match those for this species in the Pyrenean area (Ribera 1992), while in more meridional regions, such as the lower Guadalquivir, the larval development occurs in winter and spring (Montes et al. 1982).

\section{* Noterus laevis Sturm, 1834 (Fig. 4b)}

Adults linger in the pond for nearly the whole year, except in June and July, when they presumably survive in preimaginal states. Once developed into adults, a remarkable population increase occurs in August. Such a quick increase in the adult population has been verified in wetlands in Northern Catalonia by Ribera et al. (in press), whereas along the Guadalquivir (Montes et al. 1982) the cycle shows adults during the winter season and early summer. The absence of larvae is due to the fact that their capture requires specific techniques (Ribera et al. op. cit.) which have not been used.

* Rhantus suturalis (Mac Leay, 1825) (Fig. 4c) :

Larvae and adults are present in the pond from September. Since larvae complete their cycle quickly, only adults remain in winter ; they reproduce in early spring, and then leave the pond. Given its permanent condition, this wetland is used by adults as a suitable habitat for shelter in winter and reproduction in early spring. Unlike what has been attested (Montes et al. 1982) for Rhantus hispanicus Sharp in the marshy region surrounding the mouth of the Guadalquivir River, no migration towards other habitats occurs during the winter months.

* Hydroglyphus pusillus (Fabricius, 1871) (Fig. 4d) :

It is the most abundant aquatic beetle in the wetland pond. Constant presence over the annual cycle, but with a staggering population attributable to very fast larval development. The occurrence of adults all year round and its euryoecious condition are well known (Ribera 1992).

* Ochthebius viridis Peyron, 1858 (Fig. 4e) :

Like the previous species its population fluctuates during the year markedly increasing in autumn and spring. This phenology matches observations of Hansen (1987) for Northern Europe, and substantially shares the phenology in Southern Spain (Montes et al 1982) where there are two seasonal peaks, in September and July. 
Table 1. Aquatic Coleoptera recorded in the Laguna de la Nava and species phenology in the annual cycle $1991-92 .^{*}=$ only larvae, ++ = larvae and adults.

Tableau 1. Coléoptères aquatiques capturés dans la Laguna de la Nava et phénologie des espèces au cours du cycle annuel $1991-92$. * = larves seules, ${ }^{*}=$ larves et adultes.

\begin{tabular}{|c|c|c|c|c|c|c|c|c|c|c|c|c|}
\hline & JI & Au & $\mathbf{S}$ & $\mathbf{o}$ & $\mathbf{N}$ & $\mathbf{D}$ & $\mathbf{J a}$ & $\mathbf{F}$ & $\mathbf{M r}$ & A p & $\mathbf{M} \mathbf{y}$ & $\mathbf{J} \mathbf{n}$ \\
\hline \multicolumn{13}{|l|}{$\begin{array}{l}\text { ADEPHAGA } \\
\text { HAL.IPLIDAE }\end{array}$} \\
\hline Haliplus heydeni & - & $\therefore$ & 2 & 1 & - & - & - & - & - & - & - & - \\
\hline $\begin{array}{l}\text { Haliplus lineatocollis } \\
\text { HYGROBIDAE }\end{array}$ & - & 1 & 1 & 1 & - & - & - & - & 1 & 1 & 1 & - \\
\hline $\begin{array}{l}\text { Hygrobia hermanni } \\
\text { NOTERIDAE }\end{array}$ & $*+2$ & 3 & - & 2 & - & 1 & - & - & - & - & $*+3$ & $*+2$ \\
\hline Noterus clavicornis & - & - & 3 & 7 & 2 & - & 5 & 3 & 5 & 1 & 2 & 1 \\
\hline Noterus laevis & - & 24 & 7 & 7 & 3 & - & 6 & 6 & 8 & 11 & 4 & - \\
\hline \multicolumn{13}{|l|}{ DYTISCIDAE } \\
\hline Hyphydrus aubei & 4 & - & 1 & 1 & 2 & 1 & 2 & 1 & - & - & 1 & - \\
\hline Yola bicarinata & - & - & - & - & - & - & - & - & - & - & - & 1 \\
\hline Bidessus goudoni & - & - & - & 1 & 1 & 4 & - & 1 & 3 & - & - & - \\
\hline Hydroglyphus pusillus & 11 & 21 & 70 & 120 & 37 & 118 & 113 & 28 & 103 & 195 & 26 & 18 \\
\hline Coelambus fresnedai & - & - & 9 & 18 & 2 & 5 & 1 & 4 & 3 & 1 & - & 2 \\
\hline Coelambus impressopunctatus & - & - & 5 & 6 & - & - & 1 & 1 & 5 & - & - & 4 \\
\hline Hydroporus palustris & - & - & - & - & - & - & 1 . & - & 1 & - & - & - \\
\hline Hydroporus planus & - & - & - & 1 & 1 & 1 & 2 & 1 & 2 & - & 1 & 1 \\
\hline Graptodytes bilineatus & - & - & 1 & - & - & 2 & - & - & - & - & - & 1 \\
\hline Graptodytes flavipes & - & - & - & - & 1 & - & - & - & - & - & - & - \\
\hline Laccophilus minutus & $*+8$ & $*+4$ & $*+29$ & 51 & 9 & 18 & 24 & 11 & 9 & 6 & $*+7$ & $* 3$ \\
\hline Agabus bipustulatus & - & - & - & - & - & - & $* 1$ & - & $* \cdot 1$ & - & 1 & - \\
\hline Agabus melanocornis & - & - & - & - & - & 5 & 7 & 1 & - & - & - & - \\
\hline Agabus nebulosus & - & - & - & - & - & $*+2$ & - & 1 & - & - & - & - \\
\hline Rhantus hispanicus & - & - & - & - & - & $:$ & - & - & - & - & $\cdots$ & 1 \\
\hline Rhantus suturalis & - & - & $*+8$ & $*+15$ & $*+6$ & $*+17$ & 17 & 4 & $*+6$ & $* 3$ & $* 3$ & *2 \\
\hline Colymbetes fuscus & - & - & 1 & - & - & - & - & 1 & - & - & - & 1 \\
\hline Dytiscus marginalis & - & - & - & - & - & - & - & - & - & $* 1$ & $* 4$ & - \\
\hline $\begin{array}{l}\text { Cybister lateralimarginalis } \\
\text { POLYPHAGA }\end{array}$ & $* 1$ & - & 5 & 5 & - & - & - & - & - & - & $*+2$ & $=$ \\
\hline \multicolumn{13}{|l|}{ HYDRAENIDAE } \\
\hline Ochthebius aeneus & - & 3 & 1 & - & - & $\therefore$ & $\ldots \ldots$ & - & - & - & $\because-$ & - \\
\hline Ochthebius dilatatus & - & . - & - & - & - & - & 1 & - & 1 & - & - & - \\
\hline Ochthebius exaratus & - & $i 1$ & 3 & - & - & - & - & - & - & - & - & 3 \\
\hline Ochthebius marinus & - & - & - & 4 & 1 & - & 2 & 3 & 1 & - & - & - \\
\hline Ochthebius viridis & 4 & 18 & 6 & 33 & 3 & .7 & 1 & 2 & 23 & 17 & - & 11 \\
\hline Limnebius furcatus & 9 & 9 & 9 & 8 & 2 & 4 & 3 & 5 & 8 & 12 & 3 & 6 \\
\hline HYDROCHIDAE & & & & & & & & & & & & \\
\hline $\begin{array}{l}\text { Hydrochus flavipennis } \\
\text { HEIOPHORIDAE }\end{array}$ & 1 & 2 & 2 & - & 1 & - & - & 1 & 2 & 1 & 3 & 2 \\
\hline Helophorus alternans & - & - & - & - & - & - & - & 6 & 1 & - & - & - \\
\hline Helophorus asturiensis & - & - & - & - & - & - & - & 4 & - & - & - & $\because$ \\
\hline Helophorus bameuli & - & - & - & 1 & - & 1 & - & 1 & - & - & - & - \\
\hline Helophorus brevipalpis & 1 & 1 & - & 1 & - & 1 & - & 3 & 1 & - & 3 & 4 \\
\hline Helophorus griseus & 10 & 4 & 3 & 22 & 11 & 15 & 1 & 8 & 10 & 15 & - & 2 \\
\hline Helophorus lapponicus & - & - & - & - & - & - & 2 & - & - & - & - & - \\
\hline Helophorus maritimus & - & - & - & 1 & - & - & - & - & 1 & - & - & - \\
\hline $\begin{array}{l}\text { Helophorus minutus } \\
\text { HYDROPHIL.IDAE }\end{array}$ & 29 & 19 & 3 & 2 & 11 & 1 & 3 & 85 & 1 & 2 & 2 & - \\
\hline Berosus signaticollis & - & - & 3 & 2 & - & 2 & 9 & - & 5 & 3 & 3 & - \\
\hline Berosus affinis & 1 & 1 & 2 & - & 1 & - & 1 & 3 & - & - & - & - \\
\hline Enochrus fuscipennis & 6 & - & 95 & 70 & 43 & 21 & 16 & 9 & 21 & 15 & 2 & 8 \\
\hline Enochrus isotae & - & - & - & - & - & - & - & 1 & - & - & - & 1 \\
\hline Helochares lividus & 2 & 7 & 9 & 6 & 9 & 11 & 15 & 3 & 12 & 12 & 39 & $*+24$ \\
\hline Helochares punctatus & - & - & - & - & - & - & 4 & 6 & 1 & 4 & - & 3 \\
\hline Hydrobius fuscipes & 1 & - & - & 6 & 5 & 3 & 2 & 2 & 3 & - & $*+3$ & $*+9$ \\
\hline Hydrochara flavipes & - & - & - & - & 3 & - & - & - & - & - & - & - \\
\hline Hydrophilus pistaceus & 1 & $*_{2}$ & - & - & . & - & - & - & - & - & $*_{1}$ & $*_{1}$ \\
\hline $\begin{array}{l}\text { Limnoxenus niger } \\
\text { DRYOPIDAE }\end{array}$ & - & - & 4 & - & 4 & 3 & 1 & 1 & 2 & - & - & \\
\hline Dryops algiricus & - & - & $-\cdot$ & - & - & - & - & - & - & - & 1 & - \\
\hline
\end{tabular}



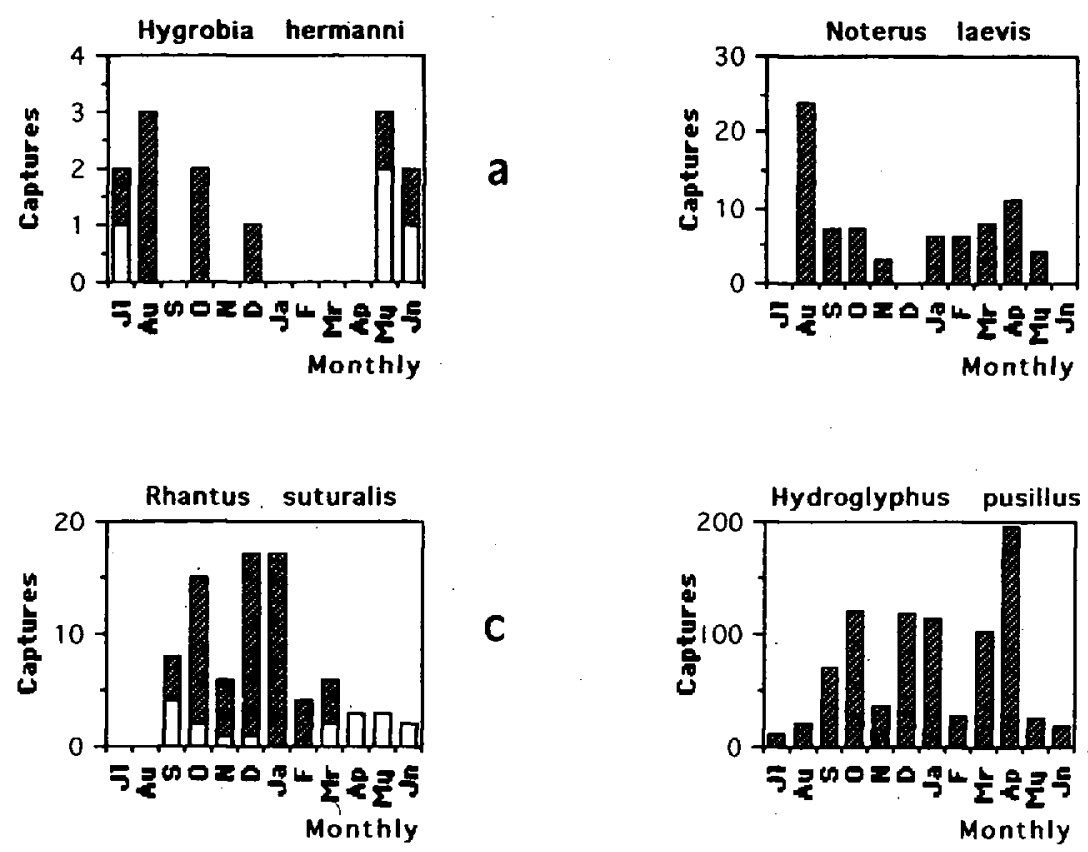

b

C
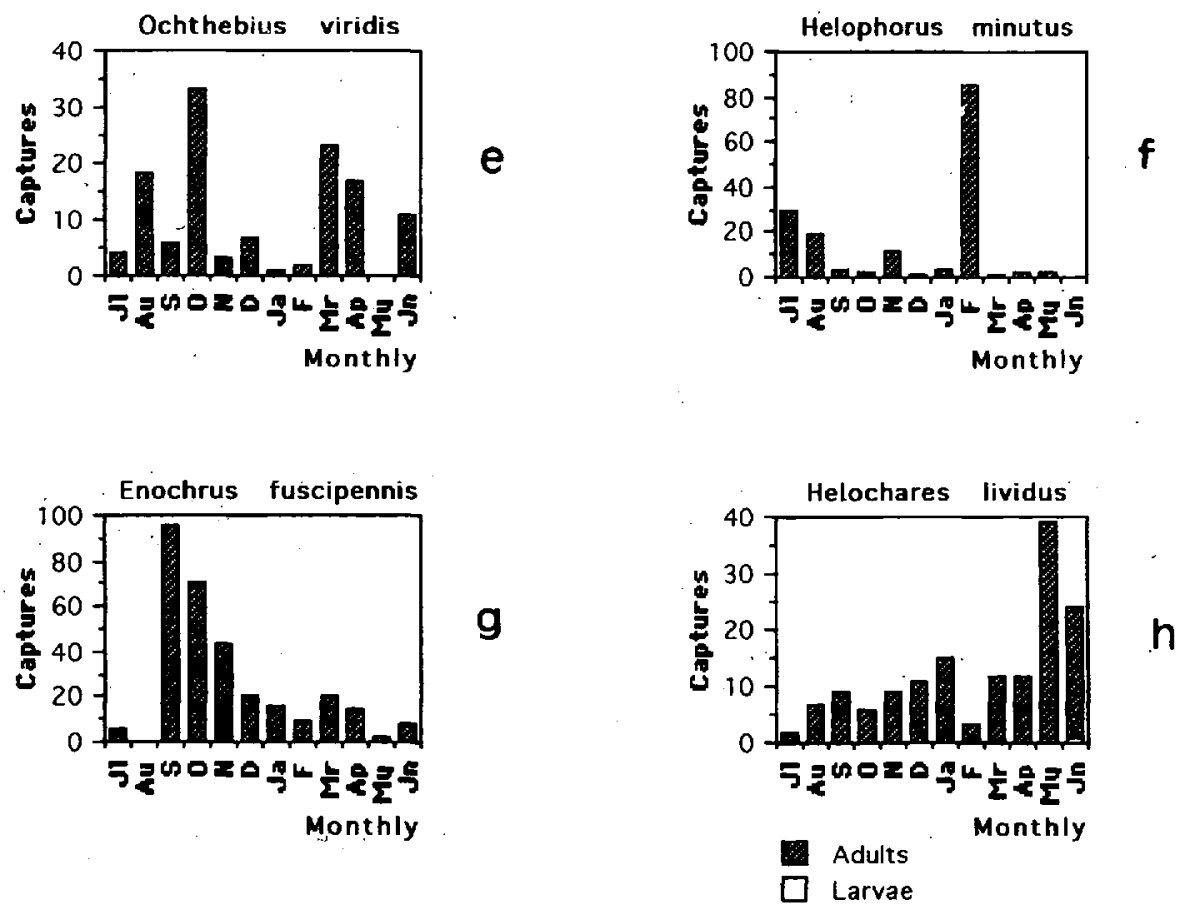

Fig. 4. Phenology of some species in the annual cycle 1991-92: Hygrobia hermanni (a), Noterus laevis (b), Rhantus suturalis (c), Hydroglyphus pusillus (d), Ochthebius viridis (e), Helophorus minutus (f), Enochrus fuscipennis (g) and Helochares lividus (h).

Fig. 4. Phénologie de quelques espèces au cours du cycle annuel 1991-92: Hygrobia hermanni (a), Noterus laevis (b), Rhantus suturalis (c), Hydroglyphus pusillus (d), Ochthebius viridis (e), Helophorus minutus (f), Enochrus fuscipennis (g) et Helochares lividus (h). 


\section{* Helophorus minutus Fabricius, 1775 (Fig. 4f) :}

Like most of the species of this genus, very sharp fluctuations in population occur depending on the suitability of conditions. In the year under study, such fluctuations materialised in February, that is, earlier than in England (Angus 1992) or Scandinavia (Hansen 1987).

* Enochrus fuscipennis (Thomson, 1884) (Fig. 4g) and Helochares lividus (Forster, 1771) (Fig. 4h):

They are two Hydrophilidae similar in size, habitat and food requirements. They are also the dominant species in this group, and, as adults, present nearly all year round. Their respective population peaks, in autumn and spring, can be interpreted as an adjustment of their biological cycle in order to avoid the interspecific competition ensuing a temporary sharing of resources.

The temporary development of the Helochares lividus population (Fig. 4h)' coincides with a rise in water temperature which signals the start of the breeding season, hence females with egg-cases were only captured from April to August. This tallies with the cycle described by Cuppen (1986b) for this species in Holland except that in these more northern populations the presence of females with egg-cases has not been recorded until mid-May. Peaks in the number of adults during the annual cycle seems to follow a latitudinal gradient ocurring in the summer time for populations in the Netherlands (Cuppen 1986b) the northern limit for this species (Hansen $1982)$; in the spring in Palencia ; and in the winter time in the marshy region of the Guadalquivir (Montes et al. 1982).

\subsection{Seasonal variation of structural parameters of the community}

Figure 5 shows the development along the annual cycle of 3 ecological parameters of the aquatic coleoptera community : richness, abundance and diversity.

Richness is minimal during the summer months and presents two peaks, in the autumn and in late spring. These peaks are accounted for by separate increases of Adephaga and Polyphaga. Factors such as pond size, climatology, seasonality or habitat variety give rise to rather diverse results in the development of richness (Montes et al. 1982).
Abundance is a very fluctuating parameter basically because of the speed at which some species, particularly Hydradephaga, complete their cycle under suitable ecological conditions (Ribera 1992).

Diversity. (Shannon index : $\mathrm{H}^{\prime}$ ) is a useful parameter to assess the progress towards more mature states in a habitat under restoration. Leaving aside values for the month of April, diversity is on the whole fairly constant and scores high values all year round. This has been pointed out by Ribera et al. (in press) for Hydradephaga althrough with somewhat lower values (2,5-3). By contrast, in La Nava it exceeds 3 almost every month ; these are similar values to those recorded in the permanent marshes of the lower Guadalquivir (Montes et al. 1982). The sharp fall in diversity during April is due to the great increase in the number of specimens of some smallsize species of Hydradephaga, and particularly Hydroglyphus pusillus. In Polyphaga diversity develops in a more constant fashion.

As a general rule, no steady in diversity - reflecting a greater degree of maturity in the system was noted during the survey.

\subsection{Autoecology and maturity degree of the wetland}

Despite the good dispersal power of most adult aquatic beetles, the detailed study of their autoecology has revealed the existence of species with strict ecological requirements which make them appear as valuable indicators in the characterization of aquatic habitats (Brancucci 1980, Castella et al. 1984, Cuppen 1986 a \& b, Flechtner 1986). The species indicating successional stages (pioneers, ubiquists and specialists) have been characterized in Central Europe by Hebauer (1988).

Among the species considered as pioneers by Hebauer (op. cit.) these have been captured in La Nava Hydroglyphus pusillus, Agabus nebulosus, Haliplus lineatocollis, Agabus bipustulatus, Hydroporus planus and Hydrobius fuscipes. These species should be considered ubiquist Hydroporus palustris, Agabus bipustulatus, Coelambus impressopunctatus, Dytiscus marginalis and Helophorus brevipalpis. Those considered as specialist are endemic taxa or with a distribution determined by ecological factors : thermophilic, acidophilic, halophilic, etc., and, most notably, several species belonging to the genus $\mathrm{Lac}$ cobius, not present in the wetland pond under study. 

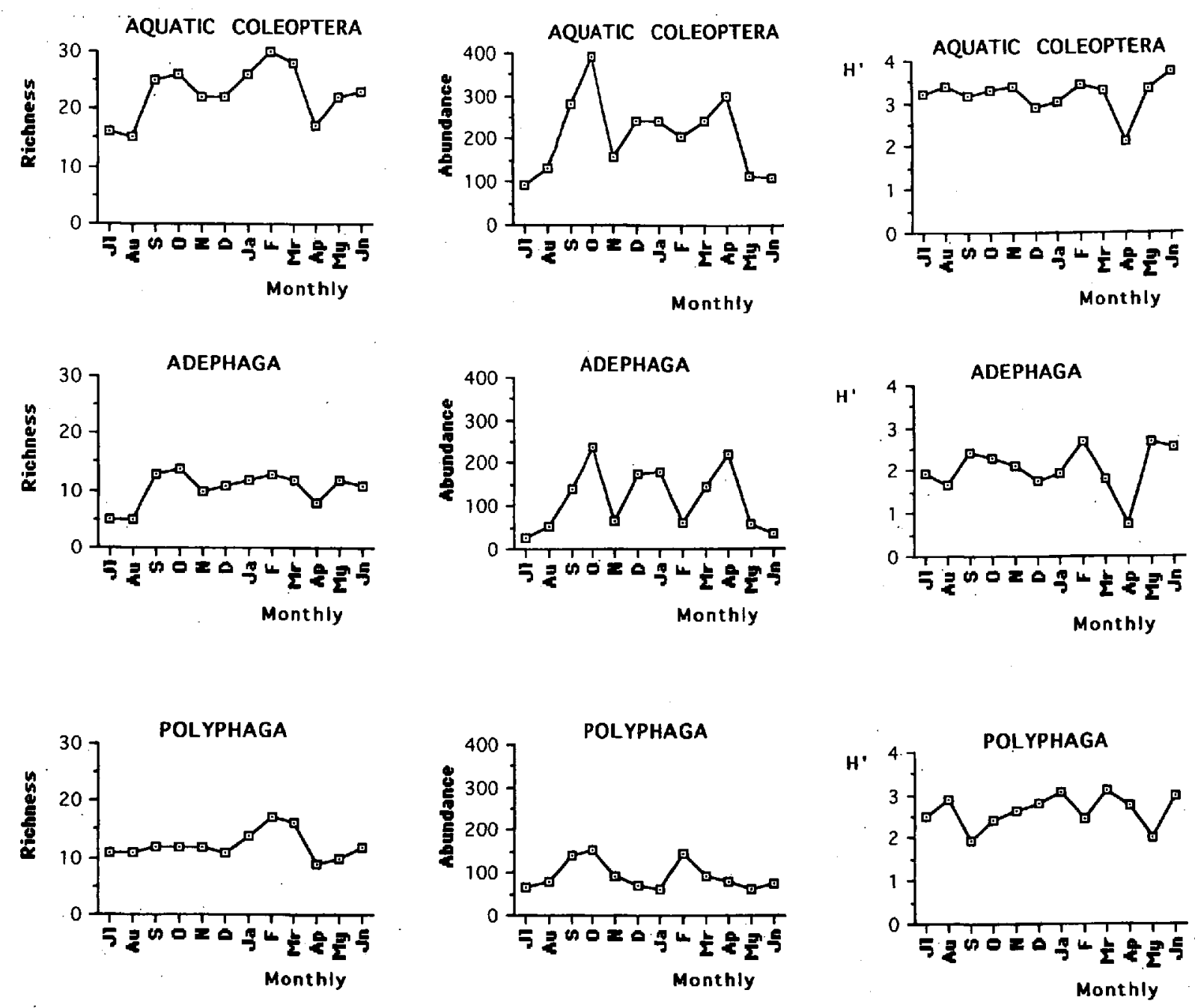

Fig. 5. Seasonal variation of richness, abundance and diversity $\left(H^{\prime}\right)$ in total water beetles and Adephaga and Polyphaga species.

Fig. 5. Variation annuelle de la richesse, de l'abondance et de la diversité ( $H^{\prime}$ ) de l'ensemble des coléoptères aquatiques et des espèces d'Adephaga et Polyphaga.

Such information, which is only partly relevant to Iberian communities of aquatic coleoptera, together with the knowledge, albeit limited, of the autoecology of many of the species considered resident, enables us to outline the characteristics of the community. Thus, during the studied period, the community of aquatic beetles in the pond corresponds to that of a medium or large-sized wetland, with abundant plant life but recent in origin.

Among, Hydradephaga, the virtual absence of species indicating former or relict habitats is striking. Only Graptodytes bilineatus could be indicative of age as it is characteristic of this wetland. In Ireland, it forms a very characteristic association along Agabus labiatus, believed to be relict, in lakes of karstic origin (Foster et al. 1992). The rest consists of species which may be classed as pioneers, good colonizers or simply ubiquists, such as Haliplus lineatocollis, Agabus bipustulatus or the species of Colymbetes or Dytiscus. In this respect, the presence of Agabus melanocornis is also significant since in England it is considered a good species indicator of temporary ponds (Eyre et al. 1992) ; it occurs in bodies of water with an average life of 2.8 months, 
and both the adult and the larva, the latter has not been captured in permanent habitats, present great affinity for ephemeral habitats.

Most of the species of Polyphaga with known autoecology are also pioneers or ubiquists which occupy the wetland just because it as a permanently flooded habitat. This is the case with Helophorus brevipalpis and Hydrobius fuscipes, well characterized by Hebauer (1988). It is also significant the complete absence of species of the genus Laccobius which has specialist species and is common in stagnant waters in neighbouring areas of the province of León (Valladares 1988). Only some species, such as Ochthebius marinus or possibly Helophorus bameuli, belong to an older fauna, their Iberian distribution being much more restricted. As far as Hydrochara flavipes is concerned, cautious consideration is in order as suitable habitats rich in plant life are available nearby, e.g. irrigation canals which may have harboured the species.

All things considered, the community of coleoptera exhibits a remarkable richness thanks to the pond's size, vegetation and permanent flooding. Nearly all of the species belong to early successional stages or are ubiquists. Future surveys should follow up changes in the wetland's faunistic composition and the anticipated increase in specialist species.

\section{Acknowledgements}

This work has been financed with the funds from a Research Project for young groups, provided by the University of Valladolid in 1991. We owe a debt of gratitude to the Environment Service of the Junta de Castilla y León in Palencia which gave us the permission to have access to the lagoon. We would like to thank Dr. J.A. Diaz Pazos (University of Santiago) and M.J. Peñin (University of León) for his help in the identification of some species, as well as Dr. G. N. Foster, Dra. L. Calvo and Dr. I. Ribera whose comments have contributed to improve the original manuscript. Finally our thanks are also due M. D. Cristobal for his help in the attainment of the project and in fieldwork.

\section{References}

Angus R.B. 1992. - Insecta : Coleoptera : Hydrophilidae : Helophorinae. Süsswasserfauna von Mitteleuropa 20/10-2. G. Fischer. Stuttgart, $144 \mathrm{p}$.

Balfour-Browne F. 1922. - The life-history of the water beetle Pelobius tardus Herbst. Proc. Zool. Soc. Lond. : 79-97.

Brancucci M. 1980. - Observations sur l'écologie des Dytiscides dans le point d'eau de la rive sud du lac de Neuchatel (Coleoptera: Dytiscidae). Bull. Soc. ent. Suisse, 53 (4) : 365-378.
Caspers N. 1983. - Sukzessionsanalyse des Makrozoobenthos eines neu-angelegten stehenden Gewässers. Arch. Hydrobiol. Suppl. $65: 300-370$.

Castella E., Richardot-Coule M., Roux C. \& Richoux P. 1984. - Macroinvertebrates as « describers » of morphological and hydrological types of aquatic ecosystems abandoned by the Rhone River. Hydrobiologia, 119 : 219-225:

Cuppen J.G.M. 1986a. - The influence of the acidity and chlorinity on the distribution of Hydroporus species (Coleoptera : Dytiscicae) in the Netherlands. Entomologica Basiliensia, 11 : 327-336.

Cuppen J.G.M. 1986b, - On the habitats, distribution and lifecycles of the Western European species of the genus Helochares Mulsant (Coleoptera : Hydrophilidae). Hydrobiologia, $132:$ 169-183.

Delgado J.A., Millán A. \& Soler A.G. 1991. — Sobre la presencia de Ochthebius (s. str.) marinus (Paykull, 1789) en la Península Ibérica (Coleoptera, Hydraenidae). Bol. Asoc. esp. Ent., $15: 339$.

Eyre M.D., Carr R., Mc Blane R.P. \& Foster G.N. 1992. - The effects of varying site-water duration on the distribution of water beetle assemblages, adults and larvae (Coleoptera : Haliplidae, Dytiscidae, Hydrophilidae). Arch. Hydrobiol., 124 (3) : 281-291.

Fernando C.H. 1958. - The colonization of small freshwater habitats by aquatic insects. 1 . General discussion, methods and colonization in the aquatic Coleoptera. Ceylon J. Sci. biol. Sci., 1 : 117-154.

Fery H. 1992. - Revision der saginatus-Gruppe der Gattung Coelambus Thomson (Coleoptera : Dytiscidae). Linzer biol. Beitr, 24 (1) : 339-358.

Flechtner G. 1986. - Association analysis of water-beetles communities (Coleoptera, Dytiscidae et Haliplidae). Entomologica Basiliensia, 11 : 297-308.

Foster G.N., Nelson B.H., Bilton D.T., Lott D.A., Merrit R., Weyl R.S. \& Eyre M.D. 1992. - A classification and evaluation of Irish water beetle assemblages. Aquatic Conservation: Marine and freshwater ecosystems, 2 : 185-208.

Franciscolo M.E. 1979. - Coleoptera Haliplidae, Hygrobiidae, Gyrinidae, Dytiscidae. Fauna d'Italia V, XIV. Edizione Calderine. Bologna : 804 p.

Hansen M. 1982. - Revisional notes on some European Helochares Muls. (Coleoptera : Hydrophilidae). Ent. Scand., 13 : 201-211.

Hansen M. 1987. - The Hydrophiloidea (Coleoptera) of Fennoscandia and Denmark. Fauna ent. scand. 18. Scandinavian Science Press. Leiden. Copenhagen : 254 p.

Hebauer F. 1984. - Der hydrochemische und zoogeographische Aspekt der Eisenstorfer Kiesgrube bei Plattling Ndby. Ber. $A N L, 8: 79-103$.

Hebauer F. 1988. - Gesichtspunkte der ökologischen Zuordnung aquatischer Insekten zu den Sukzessionsstufen der Gewässer. Ber. $A N L, 12$ : 229-239.

Jäch M.A. 1991. - Revision of the Palearctic species of the genus Ochthebius Leach. VI. the marinus group (Hydraenidae, Coleoptera). Entomologica Basiliensia, 14 : 101-145. 
Jubete F. 1992. - Proyecto de recuperación de la laguna de la Nava (Palencia). In Junta de Castilla y León (Ed.), Curso de humedales de la cuenca del Duero. Habitats de descarga de aguas subterróneas en el acuífero de los arenales. Actuaciones para su protección. Biblioteca de Educación Ambiental, Serie $C$ : Documentación Técnica de Medio Ambiente : 81-84.

Landin J. 1976. - Methods of sampling aquatic beetles in the transitional habitats at water margins. Freshwater Biology, $6: 81-87$.

Löderbusch W. 1985. - Wasserkäfer und Wasserwanzen als Besiedler neuangelegter Kleingewässer im Raum Sigmaringen. Veröff. Nat. Lands. Bad., 59/60:421-456.

Montes C., Ramírez L. \& Soler A.G. 1982. - Variación estacional de las taxocenosis de Odonatos, Coleópteros y Heterópteros acuáticos en algunos ecositemas del bajo Guadalquivir (SW. España) durante un ciclo anual. Anales Univ. Murcia (Cienc.), 38 (1-4) : 21-100.

Montes C., Muñoz F. \& Ramírez L. 1985. - Estimas absolutas y relativas de la densidad de poblaciones de Odonatos,
Coleópteros y Heterópteros acuáticos en ecosistemas de nivel de agua fluctuante. Act. I. Congr. Esp. Limnol., Barcelona : 51-60.

Ribera I. 1992. - Estudio de los Hydradephaga (Coleoptera) del Pirineo y Prepirineo : morfometría y ecología. Memoria de Tesis Doctoral. Universidad de Barcelona. 346 p.

Ribera I., Isart J. \& Régil J.A. (in press). — Coleópteros acuáticos de los estanques de Capmany (Gerona). I : Hydradephaga. Scientia Gerundensis.

Sørensen T.A. 1948. - A method of establishing groups of equal amplitude in plant sociology based on similarity of species content, and its application to analyses of the vegetation of Danish commons. Konelige Danske Videnskabernes Selskabs Skrifter, $5: 1-34$

Valladares L.F. 1988. - Los Palpicornios acuáticos de la provincia de León (Coleoptera, Hydrophiloidea). Memoria de Tesis Doctoral. Universidad de León : 454 p. 